\title{
Study of Community Capacity Enhancement in Fire Disaster Mitigation in Kuta Alam Sub-District, Banda Aceh
}

\author{
Isfani $^{1}$; Ismail AB; Nizamuddin ${ }^{2}$ \\ ${ }^{1}$ Masters in Disaster Science Postgraduate Program, Universitas Syiah Kuala, Banda Aceh, Indonesia \\ ${ }^{2}$ Faculty of Math and Science, Universitas Syiah Kuala, Banda Aceh, Indonesia
}

http://dx.doi.org/10.18415/ijmmu.v6i2.708

\begin{abstract}
Kuta Alam Subdistrict is one of the subdistricts in the Banda Aceh city that has a risk of fire disasters. This is because this area is a residential area with a moderate category. Semi-permanent buildings and temporary constructions are still at high risk of fire often found in the area. Based on the results of interviews with the Banda Aceh Fire and Rescue Service, there were 27 fire incidents from 2014 to 2017, of which 12 houses were burned down, 2 schools, 3 office units, and 10 other public facilities affected by the fire. This research is needed to improve the ability of people to prevent and protect themselves, especially in pre-disaster conditions so that they can reduce the fire incidence. The community capabilities in fire disaster mitigation are the methods used in this study. Subdistrict consist of optimizing land use in city development, minimizing street parking, increasing green open space, increasing the ability of water sources and wet towel / clothes as a method of fire outage if there is a small fire at home, access information about procedures for firing and providing early warning, and must be able to evacuate to the designated location.
\end{abstract}

Keywords: Planning; Fire Disaster Mitigation; Kuta Alam District

\section{Introduction}

Fires are disasters based on the causes of events classified as natural disasters or non-natural disasters caused by man-made disasters. Natural factors that cause fires include lightning, earthquakes, volcanic eruptions, droughts, etc., while fires caused by human factors come from gas leaks, short circuiting of electricity, cigarette cutting, sabotage, low construction construction safety systems against fire, etc. (Law of the Republic of Indonesia No. 24 of 2007).

Fire disasters arise due to the trigger factors, namely environmental conditions that have the potential for the emergence of fire and humans act as ignition fires because they carry out heterogeneous activities that create a stimulus for the appearance of fire. In general, the fire disasters that often occur in the city of Banda Aceh are caused by dry conditions and downtown areas that are densely populated, resulting in a high risk of fire. 
Disaster risk is the potential loss caused by a disaster in a certain area and period of time that can be in the form of death, injury, illness, life threatening, loss of sense of security, displacement, damage or loss of property, and disruption of community activities. Disaster vulnerability in a community is determined by the low risk of a disaster. The risk of disaster is a function of the number of threats that are directly proportional to the vulnerability that exists in the community and will be inversely proportional to the capacity possessed in the face of the disaster (BNPB, 2016).

To reduce fire risk, the steps that can be taken is to intervene in one or all of the parameters of the following equation:

$$
\begin{array}{ll}
\operatorname{Risk}(\mathrm{R})=\frac{\text { Information: }}{\operatorname{Hazar}(\mathrm{H}) \times \text { Vulnerability }(\mathrm{V})} & \mathrm{R}: \text { Risk } \\
\cline { 8 - 8 }(\mathrm{C}) & \mathrm{H}: \text { Hazar } \\
& \mathrm{V}: \text { Vulnerabillity } \\
& \mathrm{C}: \text { Capacity }
\end{array}
$$

Based on data from the Banda Aceh City Fire and Rescue Service (2018) that from 2014 to 2017 there were 287 cases of fire in Banda Aceh which caused damage to houses of 136 units, 4 schools, 1 mosque, 10 offices, 66 shops, and 11 infrastructures were burned and various other types of buildings were 49 units.

Based on the background described above, research on fire mitigation planning is needed to improve the ability of the community to prevent and cope with fires, especially in pre-disaster conditions so that they can determine the rate of fire. So the purpose of this study is: (1) Identifying fire risk in the Kuta Alam Subdistrict area based on existing conditions; (2). Identify and analyze the ability of the community in Kuta Alam District in fire disaster mitigation; and (3) Produce a plan that can be applied in Kuta Alam District.

\section{Areas of descriptions, methods and material studied}

The research was conducted in Kuta Alam sub-district, which is part of the administrative area of Banda Aceh City with an area of 1,007 ha. This sub-district consists of 11 (eleven) villages. Kuta Alam Subdistrict, is one of the Subdistricts in the City of Banda Aceh that has a risk of fire disasters. This is due to the fact that this area is a dense residential area with a moderate category (Public Housing Agency and Settlement Area of Banda Aceh City, 2017). Semi-permanent buildings and emergency construction are still at high risk of fire. In addition, household activities in this area are susceptible to fires, such as burning careless garbage, throwing cigarette butts in any place, and using electrical devices that are piled on one terminal. Based on the results of interviews with the Banda Aceh Fire and Rescue Service, there were 27 fire incidents from 2014 to 2017, of which 12 houses were burned down, 2 schools, 3 office units, 6 shops, and 4 other public facilities affected by the fire disaster in Kuta Alam District.

The population in this study were residential buildings with a number of buildings in Kuta Alam Subdistrict where 3 (three) gampongs were the study areas, namely Peunayong Village, Gampong Keuramat, and Gampong Kuta Alam which had Fire History with the number of buildings which were assumed to be 3008 buildings. building for 1 Head of Family (KK). The sample in this study was taken from the study population for questionnaires.

This research method uses a combination method (mix method) that is a qualitative method in the form of a study / descriptive qualitative approach and a quantitative method in the form of a weighting variable. This method is carried out through the disaster management approach stated in the Law of the Republic of Indonesia No. 24 of 2007 concerning Disaster Management, namely the pre-disaster stage (the stage in the situation where there is no disaster in the form of mitigation), and the study approach based on the concept of preparedness and early warning system. The mitigation phase is carried out 
before a disaster occurs to reduce or prevent the negative impact of a disaster. Mitigation actions consist of structural mitigation and non-structural mitigation. Structural mitigation is related to forms of physical mitigation, such as the construction of facilities and infrastructure.

Whereas non-structural mitigation is related to policy, awareness building, knowledge development, public commitment and implementation of methods and operations, including participatory mechanisms and information dissemination, which are carried out to reduce disaster risk. The concept of preparedness is an estimate of the needs that will arise if there is a disaster emergency and the introduction of resources to meet those needs, thus bringing people in disaster-prone areas to a relatively better level of preparedness to deal with disasters. The concept of emergency / response mitigation (Early Warning System) are actions taken immediately before or after the occurrence of a disaster.

\section{Results}

\subsection{Fire Risk Analysis}

To determine the level of risk of fire disaster in the study villages, the variables for analysis are hazard factors, vulnerability and fire resistance. The analytical method used in determining the risk of fire disaster is the determination of the benchmark of fire risk variables that have been determined using the Guttman scale.

\subsubsection{Fire Hazard Analysis}

Hazards have variable incidence of fires, vulnerable households and the presence of gas stations and traders of gas / retail fuel around the environment. For Gampong Kuta Alam, it has the highest value in terms of fire hazard because it has a maximum value of the total number of variables, while for the other two villages also has a relatively high hazard value, because almost all hazard variables have a positive value so Peunayong Village and Keuramat also have risks which is quite high.

Table 1. Assessment of Fire Disaster Risk Levels in Kuta Alam District

\begin{tabular}{|l|l|l|l|}
\hline \multirow{2}{*}{ Fire Disaster Variable } & Amount of Value \\
\cline { 2 - 4 } & Peunayong & Keuramat & Kuta Alam \\
\hline Danger & 7 & 8 & 9 \\
\hline vulnerability & 8 & 8 & 8 \\
\hline endurance & 5 & 7 & 5 \\
\hline Fire Risk Value & $11 \quad 9 \quad$ & 14 \\
\hline
\end{tabular}

\subsubsection{Fire Vulnerability Analysis}

Study of vulnerability analysis, variables to be discussed are building density, building density, building materials, road access, population density, elderly population, toddlers and disabled people, at risk households and underprivileged households. Based on the results of the fire vulnerability analysis, that the three gampongs have the same vulnerability value of 8 and have a risk value for the whole variable, so this implies that the three gampongs have high fire vulnerability.

\subsubsection{Analysis of Fire Resistance}

Regional resilience in dealing with fire disasters can be seen based on the variable presence of supporting facilities and infrastructure owned by the region. Sources of information about fire disasters and human resources in the region. 
Based on the results of the analysis, the region that has the highest score is Gampong Keuramat. In general, the capacity / resilience of a region to a fire disaster that is not owned by a fire hydrant with adequate water sources and pressures, community institutions are related to disaster preparedness and the number of extinguishing facilities in the form of extinguishing vehicles that are in accordance with community needs, especially for dense housing.

\subsubsection{Disaster Risk Level Analysis}

The fire disaster risk level analysis chosen using calculations in the Model Crunch, the calculation carried out is to accumulate hazard and vulnerability values reduced by regional resilience / capacity.

Based on the analysis of the level of fire disaster risk, it can be applied that the highest risk value is if an area has the highest hazard value, 9 assuming all indicators have a value of 1 , and the highest vulnerability assuming all indicators have a value of 1 , and have the lowest resistance value -17 assuming all indicators have a value of -1 , so the overall value of the fire disaster factor is 34 .

For the lowest fire disaster risk value is if an area has the lowest hazard value that is 0 assuming all hazard variables have 0 assuming all hazard variables have a value of 0 , and have a vulnerability value that is 0 assuming all resistance variables are 0 , and have a resistance value 17 highest assuming all resilience variables have a value 1. After knowing the value of disaster risk, the next step is to rank the value of disaster risk, then the next step is to rank the risk value by making the distribution of risk values through the Sturgess formula as follows:

1. Determine the lowest value of -17 and the highest value of 34 ;

2. Determine many interval classes with the Sturgess formula:

$\mathrm{K}=1+3,322 \log \mathrm{n}$

$\mathrm{n}=$ number of variables is 34 , so the value of the interval class (k) is 5

3. Calculates the interval class interval (i)

$$
i=\frac{\text { max Value }- \text { min Value }}{\text { Number of interval classes }}
$$

So the class length is 11

4. Enter the risk value into the interval class, namely:
a. $-17-(-17)=$ very low
b. $-6-3=$ low
c. $4-14=$ medium
d. $15-26=$ high
e. $27-37=$ very high

Based on the risk value of fire disaster in all three villages, it can be concluded that Peunayong Village, Gampong Keuramat, and Gampong Kuta Alam have a moderate risk of fire disaster risk.

\subsection{Analysis of Community Capability in Fire Disaster Mitigation}

Based on the variables to determine the level of community capacity to deal with fire disasters, it can be assessed through the ability of the community to provide local fire fighting infrastructure (household), the ability of the community to access fire disaster information and mitigation procedures, and the community's ability to carry out fire prevention procedures. 


\subsubsection{Analysis of Community Capability in Accessing Fire Disaster Mitigation Information}

Indicators of people's ability to access information about fire disasters and fire mitigation processes are the ability to access fire prevention information in buildings and the environment, the ability to access information through community institutions, and the mass media.

Based on the results of the analysis of the ability of the community to access fire disaster mitigation information for the Peunayong Village community, it is considered to have above average ability (rather high qualifications) in obtaining access to information on fire suppression procedures in the room, because almost $60 \%$ of the total respondents agreed have the ability, and almost $72 \%$ of the community knows information about procedures for extinguishing fires in the event of an environmental fire and is at a moderate level (average).

To access fire disaster information mediated by local authorities, $80 \%$ of respondents in the village claimed to have good access, this was because the community officials actively disseminated information through a circular issued by the Regional Government of Banda Aceh, as well as pamphlets and stickers given to society.

The Gampong Keuramat community is considered to have a level of ability above average in accessing information on fire prevention procedures at home and has a very high level of ability regarding fire prevention procedures in the environment and access to information through mass media.

For the results of observations and interviews that Gampong Keuramat has community institutions that are active in conducting socialization on community programs, although in particular there is no program based on disaster mitigation.

As for Kuta Alam Gampong based on the first case of a fire incident, the community has not been able to prevent the spread of fire in the environment, resulting in large losses, but in the case of the second and third fires, the community can localize the fire so that it does not spread quickly to the environment carried out without interference from the Fire Service. For access to disaster information obtained through mass media in Gampong Kuta Alam has a rather low level of ability, this identifies a lack of level of public awareness of the development of information through mass media.

\subsubsection{Community Capability Analysis in Providing Fire Fighting Facilities and Infrastructure}

Indicator of the ability of the community in providing fire fighting facilities and infrastructure is the ability to provide water resources at home which has good quantity and continuity to extinguish fire at home, the ability to provide water reservoirs placed at the front of the house, the ability to provide sand placed in potential sources of fire at home, the ability to provide extinguishers in the form of tubes, and the ability to provide communication tools to contact relevant parties who can carry out fire repetition.

Based on the results of the community analysis, Peunayong Village is considered to have a means that is above average (rather high) in providing local fire extinguishers (households) in the form of independent water sources, and providing wet laps / sacks, as well as providing telephone / cellphone and has a moderate level of ability in the provision of water reservoirs, for the ability to supply Light Fire Extinguishers (APAR) this region has a low level of capability.

For Gampong Keuramat it is considered that the ability is above average (rather high) in the ability to access information about fire prevention procedures at home, whereas in accessing information on disasters through mass media and fire prevention procedures in the environment have very high capabilities, and are based on results observations and interviews with the Gampong Keuramat community, it can be explained that the Gampong Keuramat community has community institutions that actively disseminate community programs even though specifically there are no disaster mitigation-based programs, besides because of the mutual cooperation culture with a high level of awareness among fellow citizens, making the process of saving community programs is easier.

For Gampong Kuta Alam in accessing information on how to prevent fire at home, there is a high ability, while the ability to access information about fire prevention procedures in the environment is still rather low, but for disaster information access from the mass media, the region has above average capability. (rather high). This is illustrated by the case of a fire that occurred in Gampong Kuta Alam, for 
the first fire case, the community has not been able to prevent the spread of fire in the environment, causing a large loss, but in the second and third fires, the community can localize the fire so it does not spread quickly to the surrounding environment, and prevention is carried out without interference from the Fire Service.

\subsubsection{Analysis of Community Capability in Fire Management Procedures}

The ability of the community in fire management procedures has several variables, namely procedures for preventing fire in the local area (home), procedures for fire prevention in the environment, procedures for carrying out independent evacuations to predetermined locations, and procedures for conducting evacuations by conducting briefings in groups. to a predetermined location, and procedures for carrying out early warnings in the event of a fire.

For Peunayong Village, the capacity level is above average (rather high) in carrying out fire prevention procedures at home and the environment, as well as conducting early warnings to the community. This can be implied that the community has the capability to prevent local area fires. For the independent evacuation process to the designated location, this area has a high level of capability, whereas for the evacuation direction process, this area group has the ability to carry out fire prevention;

For Keuramat Village in general has a high level of ability in fire suppression procedures for local and environmental areas, as well as conducting evacuation processes and conducting early warnings if there is a fire hazard in the environment while for Gampong Kuta Alam in general has a level of ability above average ( rather high) in carrying out fire prevention procedures in the local area as well as in conducting independent evacuations and conducting early warnings because in Gampong Kuta there had been a fire incident and the Fire Department had held a training on fire prevention in this village.

\section{Discussion}

Based on the analysis that has been carried out that the level of risk of fire disaster in Kuta Alam Subdistrict falls into the medium category with a low and high level of community capability. Based on the accumulated values of all fire disaster mitigation capability variables, fire mitigation planning in Kuta Alam Subdistrict can be carried out as follows:

\subsection{Provision of Green Open Space}

Kuta Alam Subdistrict is a central business district in the form of trade centers and services, offices and settlements. Green Open Space Planning (RTH) in vacant land in the form of pond construction is very important to consider, which will function as a backup water source in the event of a fire disaster. In addition, the Green Open Space area can be used as an assembly point when there is a fire. In this case the selection of Green Open Space as a safe point of fire due to the relatively large area and easy to reach by residents, besides that the use of land consisting of vacant land, sports fields, and residents' tombs caused the absence of buildings in the area so that fire hazards cannot spread to the area.

\subsection{Vehicle Circulation, Pedestrian and Parking Lots Settings}

Standard operational procedures according to Minister of Public Works Regulation No. 10 of 2000 concerning management of fire prevention of buildings, each building must have a building less than $10 \mathrm{~m}$, the width of the road is at least $4 \mathrm{~m}$ and a maximum of $45 \mathrm{~m}$ to facilitate the fire extinguisher. But in Kuta Alam Subdistrict, it is around 2-5 m on average, there are even roads with a width of less than $2 \mathrm{~m}$ so it cannot be traversed by fire engines. So that the right planning is a road that can be traversed by fire engines, directed so that the road is not used for parking on the street. This can be done by installing street furniture in the form of traffic signs containing appeals for prohibited parking on the roadside. This is intended so that when a fire occurs, the fire engine can pass through the roads without obstacles vehicles parked on the roadside. In addition, the on-street parking in the study area is directed so that it can be minimized as small as possible so that it can facilitate the water retrieval lane and the path for the extinguishing vehicle to the water reservoir. 


\subsection{Enhancing Community Capability in Fire Mitigation}

Based on Minister of Public Works Regulation No. 10 of 2000 concerning management of fire prevention of buildings that need to be improved by the community in the effort of fire mitigation is to provide household fire extinguishers, especially in the form of independent water sources and water reservoirs, provide communication devices (telephone / cellphone), can access information about ways to extinguish fires at home and in the surrounding environment, access information related to fire disasters, as well as the ability to evacuate and provide early warning to the community in the event of a disaster.

The training that was obtained by the community in Kuta Alam District was in the form of training on the theory of fire suppression, fire suppression using APAR, and actions taken when experiencing a fire disaster. The fire prevention training has only been conducted once. Even though the Minister of Public Works Regulation No. 10 of 2000 concerning management of fire prevention of building buildings, that the community is required to hold a minimum of 6 months training and outreach on emergency response or self-evacuation measures during a fire disaster. Therefore, community capacity building training on fire mitigation is very important to be carried out continuously to improve community preparedness against fire hazards.

\section{Conclusions}

From the results of the analysis of fire risk in the Kuta Alam Subdistrict area based on the existing conditions that Peunayong Village, Gampong Keuramat, and Gampong Kuta Alam have the risk of fire disaster in the medium category.

Based on the analysis of the ability of the community in fire disaster mitigation, it was found that Peunayong Village was in the low category of fire prevention, Gampong Keuramat was in the high category because the community had a good sense of mutual cooperation, and Gampong Kuta Alam was in the low category of fire mitigation capabilities.

Planning that can be done to reduce fire risk in Kuta Alam Subdistrict in the form of optimizing land use in the form of providing Green Open Space in Kuta Alam Subdistrict as a gathering point in the event of a fire, controlling the development of roads so as to minimize fire risk, minimize action on street on roads that can be traversed by fire fighting vehicles and water retrieval lines, increasing community capacity in fire disaster mitigation in Kuta Alam District in the form of providing water sources as a means of suppressing fires in the event of a small fire in the house providing wet laps / sacks, improving access to information how to extinguish fires at home and in the surrounding environment, and can evacuate to locations that have been established, provide early warning to the surrounding environment.

\section{References}

BNPB. (2016). Buku Risiko Bencana Indonesia. Direktorat Risiko Bencana Deputi Bidang Pencegahan dan Kesiapsiagaan. Citeureup: Sentul. [In Indonesian].

Budiman, PA. (2009). Kajian Persepsi Risiko dan Strategi Adaptasi Masyarakat Berpenghasilan Rendah terhadap Bencana Banjir Pasang (Studi Kasus: Kawasan Muara Baru, Kecamatan Penjaringan, Jakarta Utara). Arsitektur Perencanaan dan Pengembangan Kebijakan. Bandung: Institut Teknologi Bandung. [In Indonesian].

Dinas Pemadam dan Penyelamatan Kota Banda Aceh. (2018). Data Kejadian Tahun 2014-2017. Kota Banda Aceh. [In Indonesian].

Dinas Perumahan Rakyat dan Kawasan Permukiman Kota Banda Aceh. (2016). Rencana Kawasan Permukiman Kumuh Perkotaan tahun 2017. Kota Banda Aceh. [In Indonesian]. 
Farha, A. (2010). Gambaran Sarana Proteksi Kebakaran Aktif dan Penyelamatan Jiwa Plant 2. Skripsi. Universitas Islam Negeri Syarif Hidayatullah: Jakarta. [In Indonesian].

Undang-Undang Republik Indonesia No.24 Tahun 2007 tentang Penanggulangan Bencana. Lembaran Negara Republik Indonesia Tahun 2007 Nomor 66. Jakarta: Menteri Hukum dan Hak Asasi Manusia. [In Indonesian].

\section{Copyrights}

Copyright for this article is retained by the author(s), with first publication rights granted to the journal. This is an open-access article distributed under the terms and conditions of the Creative Commons Attribution license (http://creativecommons.org/licenses/by/4.0/). 